REVISTA CHILENA DE LITERATURA

Noviembre 2008, Número 73, 31 - 55

\title{
LA CRÓNICA DE JERÓNIMO DE VIVAR Y EL SUJETO COLONIAL*
}

\author{
Sarissa Carneiro \\ Universidad de Chile \\ sarissacarneiro@gmail.com
}

RESUMEN / ABSTRACT

\begin{abstract}
Este estudio se propone analizar la construcción del sujeto colonial en la Crónica de los Reinos de Chile (1558) de Jerónimo de Vivar, atendiendo a tres niveles de la misma: el sujeto cronista (soldado, cosmógrafo-geógrafo, escriba y biógrafo de Valdivia), el sujeto conquistador (Pedro de Valdivia, presentado en la Crónica como modelo heroico) y el sujeto colonizado (especialmente los habitantes del Valle Central y los entonces llamados “araucanos"). El análisis enfatiza las relaciones entre estos niveles con el fin de intentar dar cuenta de la visión que presenta Vivar en su Crónica.
\end{abstract}

Palabras clave: Jerónimo de Vivar, Crónica de los Reinos de Chile, conquista de Chile, sujeto colonial.

In this essay, I propose to analyse the construction of the colonial subject in the Crónica de los Reinos de Chile (1558) by the Spanish chronicler Jerónimo de Vivar. Three levels are studied: the chronicler, the conqueror as a subject in the Crónica and the colonized subject (especially the araucanos).

KEY WORDS: Jerónimo de Vivar, Crónica de los Reinos de Chile, Chile’s conquest, colonial subject.

* Este artículo recoge algunos planteamientos de mi tesis doctoral, "Palabras peregrinas: escritura, traducción y diferencia en Jerónimo de Vivar y Pero de Magalhães Gândavo". Tesis doctoral. Pontificia Universidad Católica de Chile, 2008. El enfoque actual tiene como marco el proyecto FONDECYT 1085189 “La Crónica de Jerónimo de Vivar: edición crítica y relectura", investigadora responsable, Raïssa Kordić y co-investigadores, Manuel Contreras y la autora. 
En los discursos producidos a partir del descubrimiento, conquista y colonización de América, la construcción del sujeto colonial aparece como asunto insoslayable. Un extenso corpus de cartas, crónicas, historias, relaciones y otros tipos textuales establece marcos discursivos en los que distintos sujetos (viajeros, inmigrantes, conquistadores, colonizadores, indios, mestizos y luego criollos) construyen una imagen de sí mismos y de los otros que da cuenta, entre otras cosas, de los juegos de fuerzas y relaciones sociales en los que estos sujetos están insertos, de las redes de poderes y negociaciones culturales en las que se involucran, de las implicaciones políticas y sociales que buscan generar con su escritura.

Rolena Adorno llamó la atención sobre la relación paradójica entre identidad y alteridad en la construcción cultural del sujeto colonial (colonizador y colonizado): "la alteridad es una creación que permite establecer y fijar las fronteras de la identidad" (Adorno, "El sujeto colonial" 67), el sujeto "se reconoce a sí mismo reconociendo al otro" y la exigencia de definir el carácter del otro surge de la necesidad de fijar los propios límites (Adorno, "El sujeto colonial" 66). En el caso de los discursos de la conquista y colonización de América entre los siglos XVI y XVII, los procesos que fijan la alteridad se apoyan, según Adorno, en la semejanza y no en la diferencia: moros, hebreos, mujeres y hechiceras son algunos de los grupos humanos que aportan modelos comparativos para la evaluación de la humanidad americana (Adorno, "El sujeto colonial" 63). El sujeto colonizador, en cuanto productor de discursos, utiliza los valores de la cultura masculina, caballeresca y cristiana como marco para la figuración de la alteridad (Adorno, "El sujeto colonial" 57); estos mismo valores son rescatados, además, por los sujetos autóctonos para "desfeminizar" la cultura nativa en sus textos "a través de dos estrategias: la racionalización y la erradicación de la 'magia' y la 'brujería', y la restauración de la historia, destacando la sociedad autóctona como agente activo (no como víctima) de su propio destino" (Adorno, "El sujeto colonial" 64).

Raúl Bueno y Elena Altuna han insistido en la condición heterogénea del sujeto migrante y viajero. El acto de migrar hace que el sujeto sea internamente heterogéneo (Bueno 173): la categoría de sujeto migrante de Cornejo Polar permite advertir, según Bueno, que las divisiones y jerarquías que enfrenta el sujeto colonial (Adorno, "El sujeto colonial") están presentes también en la esfera íntima del sujeto, en "sus encontradas historias, sus ejes culturales, valores, códigos y signos" (Bueno 173-4). El sujeto migrante es el sujeto heterogéneo por excelencia: fagocita culturas y lenguas sin diluir diferencias y problemas, señala Bueno (174). Elena Altuna enfatiza, por su parte, que 
el descentramiento es la operación que está en la base de la experiencia del viaje: el viaje pone en marcha mecanismos de readaptación y de adquisición de nuevas pautas culturales exponiendo al sujeto a su propia incomprensión de lo desconocido, es decir, enfrentándolo a sus propios límites y a los límites que le imponen los otros (Altuna, "Introducción" 9).

Actualmente, el interés por los sujetos coloniales (viajeros, conquistadores, inmigrantes, indios, esclavos) se refuerza por las diversas migraciones del presente: la situación colonial se reproduce hoy en distintas variantes, repeticiones y transformaciones que, como advierte Rolena Adorno, "estimulan la mirada hacia atrás a los sujetos forasteros de antaño" (Adorno, "La pertinencia"). Esa mirada hacia atrás arroja luces a los actuales legados coloniales al tiempo que enfrenta el pasado a nuevas preguntas.

Este estudio se propone analizar la construcción del sujeto colonial en la Crónica de los Reinos de Chile (1558) de Jerónimo de Vivar, atendiendo a tres niveles de la misma: el sujeto cronista (soldado, cosmógrafo-geógrafo, escriba y biógrafo de Valdivia), el sujeto conquistador (Pedro de Valdivia, presentado en la Crónica como modelo heroico) y el sujeto colonizado (especialmente los habitantes del Valle Central y los entonces llamados "araucanos"). Se enfatizarán las relaciones entre estos niveles (es decir, la relación entre alteridad e identidad) con el fin de advertir que el entrecruce de los mismos da cuenta de la visión que presenta Vivar en su Crónica.

\section{“DETERMINÉ DE ESCRIBIR Y PONER POR MEMORIA”: EL CRONISTA}

Por siglos, la crónica más temprana de la conquista de Chile no fue más que un nombre y una referencia a un manuscrito perdido: "Gerónimo de Bivar, Historia de Chile manuscrita", en la citación de León Pinelo. Desconocemos su travesía desde 1558, cuando el autor la da por concluida hasta las primeras décadas del siglo XX, cuando la adquiere José Chocomeli Galán, en una partida de libros antiguos en Valencia. Su primera edición (facsimilar, a plana y renglón, con transcripción de Irving Leonard) es de 1966.

Tanto antes como después del hallazgo del manuscrito y de su publicación, la biografía de Vivar fue uno de los asuntos más discutidos. Distintos autores se han referido a la autoría del manuscrito, a la existencia del cronista, a la posibilidad de que Jerónimo de Vivar fuera un seudónimo de Juan de Cardeña, secretario de Valdivia, al papel de Jerónimo de Vivar en la 
conquista de Chile, la fecha de su llegada y otros detalles relacionados con una brumosa biografía.

Uno de los antecedentes para la discusión en torno a la autoría del manuscrito y la posibilidad del seudónimo remonta al siglo XVIII: en la edición de Barcia del texto de León Pinelo, se identifica a Vivar como secretario de Pedro de Valdivia, lo que retoma luego el abate Juan Ignacio Molina.

En 1876, Luis Montt enfrenta la cuestión en los siguientes términos:

La autoridad de León Pinelo, bibliografo diligentisimo es indudable en cuanto a la existencia del libro $i$ al oficio de su autor. Es igualmente indudable que hasta 1554, fecha de la muerte de Valdivia, no hubo en Chile ninguno Jeronimo de Vivar. Los documentos que se conocen del primer período de la historia, consignan cuando menos una firma, un nombre, una referencia, algo que nos recuerda a cada uno de los conquistadores, desde el jefe hasta el pregonero, i ninguno menciona a Jeronimo de Vivar, ni las provisiones de Valdivia se ven refrendadas por otro secretario que el escribano Juan Pinel, i desde 1547 en adelante por Juan Cárdena... Nada hubiera tenido de estraño, i de ello hai ejemplo en la historia de las falsificaciones literarias, que Cardeña, joven osado i travieso, segun lo calificaban sus contemporaneos, i cuyo apellido recuerda un lugar clasico en la leyenda del Cid, al buscar un seudonimo para firmar su cronica, adoptase el apellido de Vivar del heroe castellano (citado en Antei 117).

Un año después de Luis Montt, Vicuña Mackenna se refiere a Jerónimo de Vivar como secretario del conquistador. A partir de estas referencias y teniendo en consideración la ausencia de un Jerónimo de Vivar en los documentos de la conquista de Chile, también Barros Arana supone que Vivar era el secretario de Valdivia, es decir, Juan de Cardeña (Orellana, La crónica 20).

Constituiría un hito en esta discusión la publicación de los Documentos inéditos para la Historia de Chile, recopilados por Toribio Medina. En el tomo XXII de esta obra, aparece el nombre de Jerónimo de Vivar en las declaraciones de lo que se conoce como el "proceso de Villagra". Allí declara en la ciudad de Santiago el año 1558 un Jerónimo de Vivar de "treinta y tres años, poco más o menos" que conocía a Francisco de Villagra "de once años a esta parte [...] é que conoció al dicho Pedro de Valdivia, gobernador que fué destas provincias de Chile" (Colección de documentos, Apéndice en Antei 266).

El documento no disipa, para algunos, las antiguas hipótesis que identifican a Vivar con Cardeña: a fines de los años ochenta, Giorgio Antei pretende 
sostener todavía la idea del seudónimo. Por esos años, Barral Gómez ya afirmaba que la hipótesis del seudónimo había perdido toda consistencia a la luz de la narración, ya que las actuaciones conocidas de Jerónimo de Vivar y de Cardeña no permitían sustentar ninguna coincidencia entre ellos. Al mismo tiempo, Mario Orellana, en estudio monográfico sobre la Crónica, intentaba reconstituir la huidiza biografía de Vivar planteando que el cronista habría nacido en la aldea de Vivar, probablemente en 1524 ó 1525, habría recibido algún tipo de educación en el convento de frailes jerónimos de Guadalupe del monasterio de Fresdeval, en las proximidades de la localidad de Vivar (Orellana, La crónica 29) y que, tras su paso a Chile hacia 1549, se habría desempeñado como soldado de a pie y arcabucero en distintas expediciones y viajes con Pedro de Valdivia (Orellana, La crónica 38).

Las inquietudes vinculadas a la relación Vivar-Cardeña partían, además, de las coincidencias textuales de la crónica con el epistolario de Valdivia: más allá de la hipótesis del seudónimo, se planteó que podría haber existido una relación de amistad entre el soldado de a pie y el secretario Cardeña, lo que explicaría el acceso del primero a la correspondencia de Valdivia (Orellana) o que Vivar podría haber sido secretario del conquistador, específicamente secretario de la capitanía general de acuerdo a una cita de Vicente Carballo y Goyeneche (Villalobos 14).

Barral Gómez planteó, por su parte, la posibilidad de que Vivar se contara entre los cosmógrafos-geógrafos encargados de reconocer y registrar las características de la tierra mientras acompañaban a Valdivia. Para Barral, esta hipótesis explicaría la permanente presencia de Vivar en las expediciones náuticas vinculadas a la labor geográfica y cosmográfica de la época (24).

La caracterización que hizo Mario Ferreccio del scriptorium de la conquista de Chile dio nuevas luces a esta discusión al plantear la participación de distintos personajes (entre los cuales estaría Jerónimo de Vivar) en las sesiones de redacción de documentos y cartas de la conquista y la posibilidad de que aquellos consultaran discrecionalmente el archivo, manejo que vendría a bosquejar un "modo literario" generalizado entre los relatores de la conquista. Esto se confirma en estudio reciente de Raïssa Kordić: según la autora, Vivar habría utilizado las Cartas de Valdivia no como mero lector sino como escriba de algunas de ellas, pues "tanto el usus scribendi (usos lingüísticos y estilísticos personales) como el ductus de la letra (rasgos particulares de trazado y diseño de las grafías) de algunas de las cartas de Valdivia coinciden de manera importante con los rasgos gráficos e idiomáticos personales de Vivar, observables en la Crónica" (Kordić 393). 
En relación con estas hipótesis, quisiera subrayar dos aspectos que aportan una perspectiva distinta al problema de la biografía de Vivar. Me refiero, en primer lugar, a lo que Rolena Adorno llamó la "polivocalidad" de los sujetos coloniales ("Nuevas perspectivas" 666-7). Se trata de una situación paradigmática en los discursos de la Colonia: los sujetos concentran simultáneamente variadas posiciones debido a las exigencias de las distintas facetas (político-administrativa, religioso-teológica, etc.) del proyecto del colonialismo (Adorno, "Nuevas perspectivas" 666-7). Al tener en cuenta esta polivocalidad (tan evidente en personajes como Bartolomé de Las Casas) las hipótesis relacionadas con la biografía de Vivar resultan complementarias y no excluyentes. El texto de la Crónica permite, de hecho, relacionar a Vivar tanto con los "trabajos de la guerra" (como los llamara Valdivia) como con la actividad escrituraria en cuanto dimensión relevante de la ocupación y conquista. Cosmógrafo-geógrafo, secretario de la capitanía general de Chile y escriba de algunas cartas de Valdivia, Jerónimo de Vivar habría participado activamente en el scriptorium de conquista aportando antecedentes relacionados con sus distintas funciones. Tras la muerte de Pedro de Valdivia, Jerónimo de Vivar rearticuló, probablemente, escritos diversos, anotaciones de viajes y expediciones realizadas, información general para una descripción de los Reinos de Chile, cartas y documentos del scriptorium, intercalándolos con una narración de los hechos de españoles desde la primera entrada de Valdivia, todo ello con un importante contenido biográfico que sigue la trayectoria vital del primer gobernador de Chile como modelo y ejemplo para futuros conquistadores y colonizadores. En 1558, dio forma final a un texto que apunta, en la combinación de géneros y tipos discursivos ${ }^{1}$, a la polivocalidad del sujeto cronista. El soldado, cosmógrafo, secretario y escribano se hace así cronista de la conquista de Chile y biógrafo de su primer gobernador.

Aquí se plantea, además, el segundo punto que pretendo enfatizar. Se trata de la incidencia de las funciones señaladas (especialmente de las de secretario y escribano de las cartas de Valdivia) y de la activa participación de Vivar en el scriptorium de la conquista de Chile, en la visión que presenta la Crónica

1 La Crónica intercala (e interrelaciona) el discurso cronístico (con énfasis en la narración de la conquista de Chile guiada por la sucesión temporal) con el discurso descriptivo (cercano al modelo de las relaciones de Indias) y el discurso historiográfico del tipo vita o biografía de Valdivia. Véase para este tema Invernizzi, "La representación de la tierra de Chile" y "Los trabajos de la guerra y los trabajos del hambre". 
de la conquista y colonización hasta 1558, del rol que habría desempeñado Valdivia en estos procesos, del sentido y necesidad de los mismos en el territorio de la gobernación.

En la Crónica del secretario, escribano, soldado y biógrafo de Valdivia se infiltran no solo secuencias narrativas, formulaciones y repertorio lingüístico de las Cartas del conquistador sino también argumentos de causa, propios del discurso de tipo jurídico, que tienen como objeto justificar acciones y decisiones, a partir de intenciones y finalidades. Como ha señalado Invernizzi, las cartas de relación (como otros tipos discursivos vinculados a los procesos de conquista y colonización de América), presentan estructuras características de los discursos retóricos en situación procesal, específicamente de los géneros judicial y deliberativo: en ellas, un enunciante protagonista de las acciones que narra defiende una causa con el fin de que el receptor, investido de los atributos propios de un juez, reconozca dichas acciones como meritorias y dignas de retribución (Invernizzi, "La probanza" 250). En el caso de las cartas de Valdivia, el discurso se estructura como defensa de una causa que se presenta, por un lado, como obscurum genus, es decir, causa de reducido nivel de defendibilidad debido al escaso conocimiento que de ella tiene el receptor, y, por otro, como status qualitatis, cuestión capital en litigio, puesto que está en jaque la calificación y el enjuiciamiento de los hechos derivado de la diferencia de normas a las que se atienen el enunciante y el destinatario para interpretar y juzgar los acontecimientos (Invernizzi, "La probanza” 251). De ello resulta que, en las cartas de relación de Valdivia, los recursos de la argumentatio se establezcan como defensa de estos hechos en el marco de una prueba jurídica o probanza de méritos acreedores de recompensa.

En la Crónica de Vivar, la argumentación se sostiene en la evaluación de los hechos y propósitos de acuerdo a la perspectiva que tiene el cronista de la trayectoria vital completa del conquistador y de la "perpetuación", limitada, pero lograda al fin, hacia 1558, y atribuida por Vivar a los esfuerzos fundacionales y ejemplares de Valdivia. En el marco de esta argumentación se instala la justificación de acciones a través de la exposición de los motivos de las mismas entendidos en términos de logro del bien (bonum).

Cito algunos ejemplos particularmente significativos. La "conjuración”, descubierta por Alonso de Monroy, de los almagristas que tenían intención de matar a Valdivia, "por ninguna vía podía dejar de castigar" (114), según Vivar, por lo cual la acción de ahorcar a cinco de los "que más culpados en aquel negocio eran" permitía "sosegar" a los demás involucrados en el asunto y al mismo tiempo no reducir drásticamente el número de sus hombres. En 
oposición a lo que Vivar presenta como legítimos motivos de Valdivia, los propósitos de los conjuradores (matar al general y volver a Lima) "cierto era negocio mal pensado y de prudencia muy falto, porque aquel hecho desampararan la tierra y todos se fueran de ella, y en ello no acertarían, porque si caso fuera que mataran al general, sus capitanes y ellos se mataran unos a otros, y fuera al revés de lo que pensaban" (114). Igual justificación merece para Vivar la reducción de los sesenta vecinos de la ciudad de Santiago en treinta, ya que "era gran trabajo estar repartidos [los indios] en sesenta vecinos" y para el "bien de los naturales" "convino hacer así por el pro y utilidad dicha" (185). El viaje a Perú, planeado con la "mañosa maña" que hace a Valdivia merecedor del mote de "Pedro Urdimalas", como registra el mismo Vivar, se define en la Crónica como acción que "convenía al servicio de su majestad" y "si hasta entonces no [...] lo había hecho saber era por no ser estorbado" y llevar a cabo su buen propósito de "desbaratar a Gonzalo Pizarro [...] y restituir aquella tierra" al rey, dando a entender así "cuán leal vasallo" era de la corona (191).

Con argumentos como estos, Vivar se hace eco, a lo largo de la Crónica, de la defensa que el mismo Valdivia desarrolla de sus acciones y méritos en las Cartas. Los ejemplos señalados son parte de un conjunto de hechos y decisiones de Valdivia duramente cuestionados, como se sabe, por algunos de sus hombres. Tal como resumiera Barros Arana, el acta de acusación no firmada que se conserva en relación con el proceso que enfrenta Valdivia ante el licenciado La Gasca tenía cinco puntos principales: desobediencia a la autoridad real o a los delegados del rey de quienes dependía Valdivia, tiranía y crueldad con sus subalternos, codicia insaciable, irreligiosidad y costumbres relajadas con escándalo público (Barros Arana 14). En cuanto al primer punto, la acusación se refería sobre todo a la toma de posesión del territorio chileno como comisionado del rey, al nombramiento como gobernador por el cabildo y al viaje a Perú en 1547 con el supuesto fin de ayudar al rebelado Gonzalo Pizarro. Este último hecho es narrado extensamente por Vivar con máxima cercanía a la narración que de lo mismo hace Valdivia en la carta VIII: en la Crónica, la fidelidad al rey se traduce en el apoyo total a La Gasca y el éxito de la participación militar de Valdivia contra Pizarro y sus hombres tiene como corolario retribuciones y mercedes, entre las cuales se destaca la provisión que confirma a Valdivia como gobernador y capitán general por su majestad de las provincias del Nuevo Extremo (208).

En esto, Vivar manifiesta especial cuidado, omitiendo en la Crónica cualquier alusión a un nombramiento previo, lo que incide en su propia 
escritura: con anterioridad al capítulo LXXVII, Vivar se refiere a Valdivia siempre como "general" y el epíteto de "el gobernador" es posterior, en el texto, al nombramiento simbólico cifrado en el parlamento de La Gasca

"Señor gobernador, Su Majestad os debe mucho, porque le habéis
dado la tierra, y asegurado el reino del Pirú, y franqueado la mar a
los navegantes y la tierra a los tratantes, y habéis hecho que cada uno
sea señor de su hacienda, y habéis sido parte para que se quitase la
niebla que sobre el Pirú estaba". Nunca el presidente había llamado
al coronel Valdivia gobernador hasta este punto (206, el destacado
es mío).

Las acusaciones del acta anónima no tienen espacio en la Crónica. La figura que construye Vivar de Valdivia se sostiene, de hecho, en condiciones del todo opuestas a las que se extraen de los cinco puntos de la acusación. Valdivia, como figura ejemplar que deben imitar los lectores de la Crónica que se animen a tales descubrimientos, poblaciones y conquistas, responde al ideal de vasallo servidor del monarca: amado y respetado por sus subalternos, con ellos habría padecido sufrimientos y trabajos, tratándolos con comprensión y liberalidad; ajeno a las preocupaciones materiales, habría manifestado incluso animadversión por el oro que resulta útil solo en la medida en que la moneda es el "nervio de la guerra" (52); cristiano ejemplar y hombre de valeroso ánimo, Valdivia habría sido venturoso en todo lo acaecido hasta su muerte heroica en Tucapel. De ahí las idealizaciones, omisiones y borraduras que resultan evidentes al leer la Crónica en el contexto de los otros discursos de Chile del siglo XVI.

Entre otras sobresalen las que se refieren a la codicia y al "amancebamiento" de Valdivia con Inés Suárez. La única mención a esta última en la Crónica se da en el contexto de su actuación en la destrucción de Santiago, cuando sale espada en mano dando "estocadas" a los caciques prisioneros en la casa de Valdivia "temiendo el daño que se recrecía si aquellos caciques se soltaban" (125). A ella se refiere Vivar como una "dueña honrada" que en casa del general estaba "que con él había venido sirviéndole del Pirú" (125). El grado de idealización en este aspecto se hace evidente no solo a la luz de los extensos vituperios dirigidos a Inés Suárez en el acta anónima, sino también en relación con otros discursos históricos como el de Góngora Marmolejo para quien, cabe recordar, Valdivia tenía dos cosas que "oscurecían" todas sus virtudes: "aborrecía a los hombres nobles, y de ordinario andaba amancebado con una mujer española, a lo cual fue dado" (116). El 
mismo Góngora Marmolejo pareciera dar razón también a las acusaciones de codicia contra Valdivia: según el capitán historiador la narración de su cruel muerte "a manos de bárbaros" da a entender al cristiano

que aquel estado que Dios les da es el mejor; y si no se levanta más es para más bien suyo, porque muchas veces vemos procurar los hombres ambiciosos cargos grandes por muchas maneras y rodeos [...] y es Dios servido que después de habellos alcanzado los vengan a perder con ignominia y gran castigo de sus personas, como a Valdivia le acaeció cuando tomó el oro en el navío y se fue con él al Pirú, que fue Dios servido y permitió que por aquel camino que quiso ser señor, por aquel perdiese la vida y estado (116).

Nada más alejado de la Crónica: para Vivar, la "desgracia” acaecida en Tucapel es tenida por caso de "mala fortuna" de un hombre que en todo cuanto hasta ese día había emprendido y acometido había sido "venturoso" y que, en el último momento, cual retrato final, protagoniza hazañas y grandezas junto a los valientes españoles que murieron con él en Arauco (291).

\section{"COMO ESTE DON PEDRO DE VALDIVIA LO HIZO": EL CONQUISTADOR}

Pero la imagen del sujeto conquistador se construye no solo a partir de la reelaboración que hace la Crónica de los argumentos de las Cartas de Pedro de Valdivia sino también con los ideales de vida y prototipos característicos de la crónica biográfica y la biografía española del siglo XV. La proximidad de la Crónica con esa tradición historiográfica fue someramente apuntada por Mario Ferreccio, quien instaló el texto de Vivar en la línea de las crónicas medievales de personaje como la serie de los reyes de Castilla, del Gran Capitán o los Hechos del condestable don Miguel Lucas de Iranzo (43). Como rasgo común, Ferreccio apuntó a la identificación de los "hechos" (entendidos como "hazañas") de un personaje "heroificado" como materia de estas crónicas (43).

A propósito de la biografía como tipo historiográfico, Romero propuso la distinción entre el héroe fundador, el héroe legislador y ordenador de la vida política, social y religiosa, y el héroe de la epopeya como expresión de los ideales colectivos (25). La heroificación que Vivar hace de Valdivia se inclina principalmente hacia el tercer tipo señalado. Como aclara Romero, en esta configuración heroica el individuo es entendido como sujeto de un 
devenir histórico y es despojado de los caracteres individuales que aluden a una personalidad singular para construir sobre él el proceso histórico de una comunidad y los ideales vigentes en ella (26-27). La forma extrema de este tipo biográfico es el arquetipo, que actúa tanto en la epopeya como en la hagiografía medieval (Romero 28-45).

En el contexto de un Renacimiento que en Italia rompe con estos arquetipos al mismo tiempo que elabora los suyos propios como el sabio humanista o el artista creador, la biografía española del siglo XV manifiesta una curiosa perduración de los arquetipos medievales con un alto valor en cuanto testimonio de los ideales de vida de la España de la época (Romero 58). En textos como Generaciones y semblanzas (1455) de Pérez de Guzmán y Claros varones de Castilla de Hernando del Pulgar, se manifiesta la fuerza del arquetipo cuando, aun en el retrato físico y moral, como instancia propicia a la aprehensión de la singularidad, el biógrafo debe dar cuenta de aquello que revela inequívocamente la calidad de los dos estados fundamentales contemplados, el caballero y el prelado, formas arquetípicas que corresponden al cuadro de ideales medievales (Romero 57). Según Romero, ni siquiera en Pulgar, a fines del siglo XV, se rompe totalmente con la "coacción del ordenamiento estamentario para la selección y valoración de los elementos de la conducta individual" (69). Así, el linaje del individuo determina y precisa la condición social, dando razón, además, de la dimensión histórica del personaje (Romero 53).

En el marco de estos resquicios adquiere sentido la presencia de atributos de persona vinculados a los antepasados de Valdivia en la Crónica, integrados a una narración que corresponde más bien a los logros de un valor individual que, acompañado de la buena "ventura", se hace merecedor de reconocimiento y retribución. En el texto de Vivar, Valdivia es portador, además, de virtudes arquetípicas del caballero presentadas por la biografía española del siglo XV. En ésta, como señala Romero, junto a las virtudes cardinales, prudencia, templanza, justicia y fortaleza, se espera que el caballero tenga firme fe en Dios, horror a la avaricia, lealtad con reyes, vasallos y amigos, se aleje de malos varones y mujeres fáciles, hable con seso y no tema a la muerte, sea prudente en preguntar y responder, tenga madura discreción, magnanimidad, fiereza, ansias de gloria y fama bien ganadas (Romero 72-73).

Hacia fines del siglo XV, y especialmente en la obra de Pulgar, tiene lugar una incipiente deformación de estos ideales medievales a través de la incorporación de elementos renacentistas como la figura del capitán y del político allegado a la corona, un sentido de realidad y una justificación de la 
apetencia de riquezas y bienes materiales, junto a la idea de fortuna y buena constelación como guía de los destinos individuales (Romero 80-86). La integración de virtudes arquetípicas que corresponden al ideal medieval del caballero en una figura cercana al capitán que, con sentido maquiavélico, justifica medios con fines, hace que el contenido biográfico de la Crónica combine contenidos que apuntan a los cambios sufridos por la biografía española hacia fines del siglo XV.

En este aspecto, el modelo de conquistador que crea Vivar a partir de su biografía de Valdivia debe ser puesto en relación, además, con el que se constituyó en paradigma de conquistador de Indias: Hernán Cortés. Como ha señalado Beatriz Pastor, la caracterización que hace Cortés de sí mismo en sus cartas está anclada en la convergencia de la concepción de mundo medieval con la renacentista: en el marco de una concepción medieval, la transformación de Cortés de rebelde en modelo se fundamenta en la figura del vasallo cristiano integrado a la jerarquía de poder que encabezan Dios y el rey, mientras que, como jefe excepcional, Cortés formula implícitamente una filosofía política que remite a una concepción renacentista que separa política y principios cristianos en la línea de lo propuesto por Maquiavelo (Pastor 123-4).

Me interesa subrayar, entre las características renacentistas que de acuerdo a Pastor presenta Cortés, las que se actualizan también en la biografía que Vivar hace de Valdivia. Por un lado, en cuanto guerrero y militar, Cortés dicta un modelo cuyo valor alcanza dimensiones míticas y sobrehumanas, con énfasis en el éxito personal del conquistador (Pastor 130-1); el modelo de militar guerrero que instala Cortés se caracteriza, además, por su mérito táctico y estratégico, así como por el uso calculado de la violencia y el terror (Pastor 133). En su dimensión de político, Cortés proyecta una conquista a partir de negociaciones, alianzas y persuasiones que, de fracasar, ceden lugar a los ataques, lo que produce un equilibrio entre severidad y clemencia (Pastor 135-6). Convertido en gobernante, el militar y político transforma la dureza en magnanimidad y sustituye el modelo del saqueo por el del desarrollo general de los recursos de la colonia (Pastor 140).

Aunque con el énfasis puesto en los ideales medievales representados por el arquetipo del caballero, la Crónica presenta a un Valdivia que en sus acciones actualiza algunos de los rasgos cortesianos mencionados. Como personaje aglutinante que posibilita y otorga sentido a la empresa, Valdivia pretende proyectar una dimensión sobrehumana (de sí mismo y 
de sus hombres) a sus oponentes indígenas. En el marco de este intento se instala la división en cuatro partes tras la llegada al valle de Mapocho: allí, los indios "topaban en cualquier parte con los cristianos y a esta causa creyeron que había muchos cristianos, que habían venido y estaban en la tierra", ejercicio y "diligencia importante" en la que estuvieron veinte días padeciendo "incomportable hambre" hasta que vinieron los caciques de paz (Vivar 102). De esta dimensión había dado cuenta Valdivia en sus cartas cuando cifra en la palabra indígena "zupai" el efecto que tiene el estado de máxima alerta que el conquistador requiere de sus hombres en el contexto de los numerosos trabajos de la guerra y del hambre padecidos en los primeros años de conquista:

conveníame tener a la contina treinta o cuarenta de caballo por el campo, invierno y verano y acabadas las mochillas que llevaban, venían aquellos y iban otros; y así andábamos como trasgos, y los indios nos llamaban de zupais, que así nombran a sus diablos, porque a todas las horas que nos venían a buscar - porque saben venir de noche a pelear- nos hallaban despiertos armados $\mathrm{y}$, si era menester, a caballo; y fue tan grande el cuidado que en esto tove todo este tiempo, que, con ser pocos nosotros y ellos muchos, los traía alcanzados de cuenta (Valdivia 34).

Efecto similar logra, según Vivar, el mecanismo de información que tiene Valdivia: "le temían demasiadamente los indios al general" (144), "tanto los perseguía que decían los indios que no era hombre mortal porque aun no acordaban de pensar la cosa cuando él ya sabía por entero" y "para efectuar esto siempre tenían lengua y aviso de lo que los caciques acordaban y pensaban hacer" (132). Otras acciones vinculadas a esta faceta de estratega y político se refieren a la "cautela" y "astucia" en el trato de paz con los indígenas que "siempre están fundados en cautelas y traiciones" (Vivar 78) y a las negociaciones y el aprovechamiento de las divisiones internas como las del valle central ("mandó el general a sus caballeros que nadie se desmandase, ni matase indio ninguno, porque podrían ser aquellos sus amigos, pues estaban diferentes con los demás indios" 96-97).

En concordancia con la imagen de vasallo ideal, Valdivia aparece en la Crónica haciendo uso permanente de los recursos pacíficos para la integración de los indígenas del Nuevo Extremo al sistema de vasallaje del que es parte. La persuasión se centra, en este caso, en la presentación infaltable en todo contacto inicial del contenido básico del "requerimiento": 
El general Pedro de Valdivia dijo que les quería decir cómo Su Majestad le había enviado a poblar aquella tierra, y a traerlos a ellos y a su gente al conocimiento de la verdad, y que venia [a] aquel efecto con aquellos caballeros que consigo traía, y a decirles y darles a entender cómo habían de servir a Dios, y habían de venir al conocimiento de nuestra Santa Fe católica y devoción de Su Majestad, como lo habían hecho y hacían todos los indios del Perú. E que entendiesen que si salían de paz y les servían, y les daban provisión de la que tenían, que haciendo esto los tendría por amigos y por hermanos, y que no les harían daño ninguno en su tierra, ni en sus indios y mujeres e hijos, ni en sus haciendas, ni los llevarían contra su voluntad; y que si se ponían en arma y le defendían el camino y el bastimento, que los matarían y robarían la tierra (76).

Se trata, sin embargo, de una presentación formal que se acompaña del uso sistemático de la violencia. Esto tiene su máxima expresión en las sesiones de interrogatorio narradas (y en algunos casos presenciadas) por Vivar, así como en la difusión del castigo ejemplar. El primer cuerpo mutilado que se transforma en ejemplo disuasivo para la resistencia indígena es el del cacique Tanjalongo. Acerca de ello indica Vivar:

Luego que fue venido el cacique Tanjalongo y presentado ante el general, mandóle cortar los pies por la mitad. No le mataron, puesto que sus culpas lo pedían, porque era cacique tenido, y que por su aviso y respeto podían venir muchos caciques e indios de paz, así como era parte para munillos que viniesen de guerra, y también porque con matarlo no pagaba lo que debía ni el mal y daño que por su causa habíamos recibido, y con cortarle los pies le seria más castigo. Y los indios, viendo que aquel cacique estaba en la casa en su tierra, por consentidor e inventor del alzamiento le habían cortado los pies, y otros diez caciques muertos, estarían temerosos y no cometerían traición (149).

Este "género de castigo" que, según Vivar, es el "más conveniente" para los indios, también será utilizado por Valdivia desde sus primeras incursiones en el territorio al sur de Santiago. En el primer enfrentamiento, "el general... mandó a quince soldados que saliesen con él, y arremetieron como suelen [...] mataron más de treinta, y todos los demás tomó, y los mandó castigar cortándoles las narices", así los envió para que "dijesen a sus caciques que si no venían a servirles, que así los habían de castigar, y que tomasen de aquéllos aviso, y que escarmentasen" (180-1). 
La presencia de estos elementos se prolonga en la medida en que la resistencia indígena no cede a las estrategias ni a la violencia de los españoles, lo que restringe las facetas de gobernante y político de Valdivia a los espacios "conquistados", extendiendo el aspecto de guerrero y militar hasta el último día de su vida, en la batalla de Tucapel.

\section{"Y QUE SEAN TAN CRUELES Y QUE EN ELLOS NO HAYAAMOR NI CARIDAD”: LOS INDIOS DE CHILE}

El discurso caballeresco militar que sienta las bases para la construcción del sujeto conquistador como vasallo cristiano y capitán de Indias fundamenta también la imagen del natural de Chile en la Crónica. Dos concepciones resultan fundamentales en el texto de Vivar: la de los indios como infieles que rechazaron una evangelización prehispánica y la de los araucanos como guerreros comparables a los pueblos prerromanos en el marco de una historia de conquistas imperiales.

El primer caso se anuncia desde el proemio, cuando el cronista expone una "culpa" que precede a la entrada de españoles en tierras chilenas:

Puesto que éstos [infieles] quisiesen disculparse que no les fue manifestado, no tendrían buena disculpa, porque entre ellos de sus pasados ha venido de mano en mano. Dicen que antiguamente anduvo un hombre que se puede creer que fue apóstol por estas tierras, como en otras provincias se ha visto muy cierto, y que ellos por ser tan malos no quisieron entender aquello que les decía (42).

La afirmación del proemio se retoma en el cuerpo de la Crónica, en el relato de los caciques del Valle Central que vienen a recibir a Pedro de Valdivia en paz. Según el cronista, ellos dijeron:

Que ya sabían y tenían noticia por dicho de sus antepasados, que 'por esta tierra anduvo antiguamente un hombre de vuestra estatura y con la barba crecida como algunos de vosotros' y que lo que este hombre hacía era curar y sanar los enfermos, lavándolos con agua, que hacía llover y criar los maíces y sementeras, y que cuando caminaba por las sierras nevadas, encendía lumbre con sólo el soplo, y hablaba generalmente en sus lenguas y lenguajes a todos, y les daba a entender cómo en lo alto de los cielos estaba el criador de todas las cosas, y que hacía vivir a todas las criaturas, y que tenía 
allá arriba mucha cantidad de buenos hombres y buenas mujeres. Y de estas cosas les decía. E que pasado cierto tiempo se salió de esta tierra y se fue hacia el Perú. Y pasado cierta cantidad de tiempo y años vinieron los ingas (104).

El cronista retoma la voz explicando que la "predicación" de ese hombre "al cual creemos ser apóstol, pues predicaron por todo el universo" (104) se pervirtió con la llegada de los incas y la instalación de la idolatría y culto al sol y a las "guacas". Añade, además, una explicación a la partida del supuesto apóstol a tierras peruanas: "viendo aquel santo varón que su santa dotrina y predicación no hacía impresión en sus empedernidos corazones, acordaría salirse de estas provincias e irse a las del Pirú" $(104)^{2}$.

El relato de los caciques se hace necesario en una escritura que pretende instalar una continuidad entre este "santo varón" y los españoles, "solos y peregrinos cristianos" (123), que emprenden la conquista. En el marco de esta intención, Valdivia mismo (y no los clérigos que lo acompañan) pareciera retomar la evangelización truncada del apóstol que, como Almagro, renunció a Chile optando por Perú. El providencialismo de la empresa se evidenciaría,

2 Vivar se apoyaba, probablemente, en noticias escuchadas en Perú, antes de su venida a Chile. Como advierte Pierre Duviols, en Paraguay y en el Perú hay noticias de una evangelización prehispánica a partir de 1548: la tradición toma forma sobre todo alrededor de 1550 (Cieza de León, 1549, Betanzos, 1551, Cristóbal de Molina 1552) con las referencias al misterioso personaje que, en palabras de Betanzos, "traía en las manos cierta cosa que a ellos les parece el día de hoy como estos breviarios" (citado en Duviols 59). El mito indígena de la creación, en contacto con la tradición religiosa europea da origen a la leyenda del apóstol, sostiene Duviols (61). Junto al hipotético Santo Tomás peruano, San Bartolomé sería identificado como primer apóstol del Perú (por ejemplo, en Guamán Poma, Duviols 66). Entre los relatos que señalan la presencia de apóstoles en América, el más temprano se refiere, no obstante, a Brasil: data de 1514 la primera noticia que, según Buarque de Holanda, apunta a este mito en la costa de América portuguesa (106). En la Nova Gazeta Alemã, el relato de unos viajeros señala la memoria de la predicación evangélica de Santo Tomás entre los naturales de la costa, dando inicio a la difusión del mito en torno a las pisadas que del apóstol habría en el interior de Brasil (Buarque de Holanda 106). En su origen, esta noticia aparece como transfiguración americana de la inmemorial leyenda que asocia los cristianos de India a la predicación de Santo Tomás (Buarque de Holanda 104). En cuanto tal, se nutre de la transposición del imaginario asiático a América, que parte de la presunción de origen colombino de una relación entre el nuevo continente y Asia, aprovechándose además de las coincidencias fónicas entre el indígena Zumé, probable héroe civilizatorio y Tomé, Tomás en portugués (Buarque de Holanda 109). 
además, en las apariciones milagrosas de Santiago Apóstol y la Virgen en batallas cruciales contra los indios de Chile. El otrora Santiago Matamoros aparece como un "viracocha viejo" en el relato de los indígenas presos tras la destrucción de Santiago:

Prendiéronse muchos. E preguntándoles que por qué huían temerosos, respondían: porque un viracocha viejo en un caballo blanco vestido de plata con una espada en la mano los atemorizaba, y que por miedo de este cristiano huyeron. Entendido los españoles tan gran milagro, dieron muchas gracias a nuestro Señor y al bienaventurado señor Santiago, patrón y luz de España (126).

En el ataque al fuerte instalado en lo que será luego Concepción, habría sido la Virgen la que habría ahuyentado a cerca de sesenta mil indios de guerra (248):

Cortándole las manos a estos indios habló con algunos, y decían todos a una que no habíamos sido parte nosotros para con ellos sino una mujer que había bajado de lo alto y se había puesto en medio de ellos, y que juntamente bajó un hombre de barba blanca y armado con una espadacha desnuda y un caballo blanco. Y visto por los indios tan gran resplandor que de sí salía, les quitaba la vista de los ojos, y que de verlo perdieron el ánimo y fuerzas que traían (249).

En el marco de este discurso providencialista, el motivo de una primitiva evangelización pretendía dejar en evidencia, como indica Altuna, "la imposibilidad del indígena en aquel lejano momento, de aprehender los misterios de la fe" (El discurso colonialista 49), constituyéndose así en signo del destino providencial de España y Portugal en la conquista de América ya que, en cuanto "origen", las huellas de esa evangelización primitiva venían a atestiguar "una promesa diferida" (Altuna, El discurso colonialista 50).

Pero constituye, además, la base para la asimilación del indígena de Chile a categorías asociadas en el imaginario europeo al moro, al infiel y al bárbaro. En la línea de lo afirmado por López de Gómora (en su célebre "Comenzaron las conquistas de indios acabada la de moros porque siempre guerreasen españoles contra infieles" 5), la idea de una evangelización prehispánica en Chile daría lugar a una concepción de la conquista como reconquista prolongada (Ainsa) en la Crónica. Figuraciones como "esta gente bestial", "estos bárbaros", estos “infieles", pretenden establecer, además, una inferioridad en el plano cultural, moral y religioso. Habitualmente, estos planos se presentan 
vinculados, estableciéndose correspondencias entre la ausencia de códigos caballerescos o el rechazo al sistema de vasallaje y la vida "silvestre", en "pecado" y "engañada por el demonio".

Por último, el demonismo es otra de las asociaciones permanentes en el discurso caballeresco militar de la Crónica: con regularidad, las observaciones en torno a aspectos religiosos y rituales autóctonos son tematizados como "pacto con el demonio" o "reverencia" al mismo ("insistidos por el demonio, acostumbran hablar con él los que por amigos se le dan" 64, "hablan con el demonio" 84, "en esto los tiene ciegos el demonio" 236, etc.). Como señala Foerster, la insistencia de los primeros cronistas en subrayar el lazo indígena con el demonio se relaciona con la ideología medieval europea sobre la hechicería: hechiceros y brujos adquirían su poder gracias a un pacto con el demonio a quien adoraban, negando a Dios y cometiendo, así, el más grave pecado de base herética (Foerster 18).

En cuanto a los araucanos, las primeras impresiones apuntan en la Crónica al poderío bélico mapuche. Algunas descripciones dan cuenta del asombro inicial: a orillas del Bío-Bío, un escuadrón comienza a "tañer sus cornetas [...] marchando hacia nosotros sus picas caladas y los flecheros sobresalientes" acometiendo "con tanto ímpetu y alboroto y gran alarido [...] que jamás pudieron romper a los indios [...] tan recios los palos y tan espesos que daban a los caballos en las cabezas, que les hacían empinar y revolver para atrás" (245).

La narración de estos contactos iniciales da paso, posteriormente, a un detallado discurso descriptivo centrado en lo bélico. Con finalidad utilitaria de advertencia pero también con admiración, Vivar describe capas verdugadas, celadas con un solo ojo, cubiertas con cabezas de león, zorros, gatos y otros animales, plumajes, picas de hasta veinticinco palmos, cuerdas, hachas de pedernal y de tres picos, garrotes, lanzas de astas de quince palmos, etc.

Pero la imagen del guerrero araucano permite, en la Crónica, la construcción de una cronología que jerarquiza la alteridad y la dispone en términos de inferioridad (cultural, histórica) a partir de una fisura creada entre el tiempo indígena y el tiempo del conquistador español. Este discurso se construye a lo largo de la Crónica y tiene como herramienta fundamental las comparaciones del mundo clásico con el mundo americano y el europeo español.

En su conjunto, estas imágenes persiguen la inscripción del pasado y la memoria indígenas en la linealidad de una historia que se pretende universal: la de las conquistas imperiales. En cuanto tal, esta historia sirve al cronista de marco para el establecimiento de jerarquías signadas, en este caso, por su 
ubicación en esa trayectoria y cronología. Arrastra, por lo tanto, consecuencias para el presente y el futuro de las culturas que habitan el territorio de la "Nueva Extremadura" al momento de su conquista. En cuanto paradigmas de encuentros (y desencuentros) con la alteridad, estas imágenes contemplan, además, modelos de enfrentamiento que resultan escasamente aplicables a la situación colonial en América del siglo XVI: su operatividad radica, no obstante, en la fuerza simbólica con que adjudica a España, en cuanto heredera de una tradición de conquistas, el rol (y el destino) civilizador de culturas y pueblos que se resistían, con bélico poderío, al sometimiento de la colonización.

Estas comparaciones con el mundo clásico construyen una linealidad que asimila por semejanza a españoles, incas y mapuches con romanos, macedonios e ibéricos prerromanos, respectivamente. Pretenden dar cuenta, al mismo tiempo, de una temporalidad discontinua y de niveles más o menos alcanzados de acuerdo a criterios bélicos y militares.

En el extremo superior jerárquico, los españoles de la Crónica de Vivar se presentan como continuadores de la tradición imperial romana, con la ventaja histórico-moral de que representan la "fe verdadera": "tomemos ejemplo de los romanos que por esta vía [...] sojuzgaron y señorearon el mundo", en el llamado de Valdivia tras la destrucción de Santiago, "más justa y más cierta es nuestra razón, pues lo hacemos con celo de cristiandad, ensalzando nuestra Santa fe católica y ensanchando nuestra religión cristiana” (127). La asimilación se confirma a través de las comparaciones entre araucanos y numantinos y cartagineses enfrentados a romanos ${ }^{3}$. Dos episodios, luego

3 Estas imágenes guardan relación con asuntos que exceden los límites de este trabajo. Me refiero a la "traslatio Imperii" y al uso de analogías y comparaciones culturales para dar cuenta de distintas culturas de América. A partir de la teoría de los cuatro Imperios mundiales, presente en toda la historiografía de la Edad Media, se elaboró una interpretación de la historia indígena fundada en la "suposición de Reinos o Imperios que marcaban etapas sucesivas de la historia” (Góngora 213). Esta elaboración se centró en los “imperios” azteca e inca, omitiendo de este esquema intelectual a otros pueblos y grupos indígenas (Góngora 214). En relación con la Crónica de Vivar, interesa subrayar que este esquema intelectual planteaba etapas en un curso ascendente general de la civilización e imponía, como señaló Mario Góngora, "una medida de unificación intelectual en las tradiciones indígenas" (215). La comparación de Vivar entre españoles y romanos, incas y macedonios, araucanos y numantinos o cartaginenses, apunta, asimismo, al extendido uso en el siglo XVI de analogías culturales. En autores como Bartolomé de las Casas, la comparación de los indígenas con griegos y romanos deviene en apología de los habitantes originarios de América (véase Góngora 218). Hacia fines del siglo 
inmortalizados por la poetización de Ercilla, cumplen esta función en la Crónica de Vivar: la acción del indio (aquí anónimo) que animaba a los hombres de Teopolicán con el ejemplo de sus miembros mutilados y la reacción de la mujer del mismo Teopolicán al ver a éste hecho prisionero de españoles:

Contaré de un indio que venía en esta haz que rompió el gobernador, el cual era uno de los que cortaron las manos que he dicho. Venía sargenteado y animando de esta manera: "Ea, hermanos míos, mira que todos peleéis muy bien, y no queráis veros como yo me veo sin manos, que no podréis trabajar ni comer si no os lo dan!"Y alzaba los brazos en alto enseñándolos para provocarlos a más ánimo [...] Quíselo poner aquí por no me parecer razones de indios, sino de aquellos antiguos numantinos cuando se defendían de los romanos (335)

[...] prendieron al Teopolicán y muchos indios e indias. E viniendo por el camino acertó a encontrar una india que era la mujer del Teopolicán e traía un niño de un año. Y como ella no pensaba que venía preso el Teopolicán e le vio, comenzó a decirle: “¿Cómo? ¿Tú eres Teopolicán, el valiente que decías que no te había de parar cristiano que no le habías de matar [...]? Y parécete cual vas atado e que tenga yo hijo de un hombre tan cobarde como tú?"E lo arrojó de una cuesta abajo, e murió el niño. Cierto me parece grande ánimo y esfuerzo de mujer, que la podíamos comparar aquella buena mujer cartaginesa que se metió con dos hijos en el fuego, porque el marido se había entregado a los romanos (342).

La asociación araucanos-numantinos se refuerza en la imagen que utiliza Vivar en la conclusión de su capítulo descriptivo dedicado a la "orden que tienen cuando vienen a pelear" (Capítulo CIV): "me parece a mí, en los ardides que tienen en la guerra y orden y manera de pelear, ser como españoles cuando eran conquistados de los romanos" (265).

Por su parte, la imagen del imperio inca, en la figura de Huayna Cápac, “otro segundo Alejandro", según la comparación de Vivar (80) viene a afirmar,

XVI, la conocida clasificación de José de Acosta de los distintos niveles de civilización y de organización política ubica a grupos como los araucanos en el extremo de la barbarie (véase Pagden 225). En una posición intermedia, Vivar, si bien enfatiza la valerosidad del adversario araucano, lo contrapone a incas y españoles, estos últimos, herederos de los romanos. 
nuevamente, la superioridad española en materia militar: el "pucarán" diaguita en el que los indios se defendieron por un año y más del "príncipe del Perú" y sus más de "treinta mil indios de guerra", es ganado por Valdivia en tan solo "una hora" y con "pocos cristianos" según la Crónica (82).

Estas imágenes dan cuenta no solo de la concepción etnocéntrica de Vivar sino también del signo que tiene la colonización del pasado y la memoria indígenas en el texto de Vivar. El énfasis en el aspecto bélico-militar de esa historia universal de conquistas en la cumbre de la cual se situaría el español conquistador en Chile, implica la omisión y tachadura de las categorías autóctonas en la conceptualización de su propio pasado. Es decir, implica la imposición de un vector histórico de dirección definida a un mundo de circularidades mítico-religiosas.

Como advierte Walter Mignolo, esta colonización se asienta en la creencia de que las diferencias pueden ser medidas en términos valóricos y los valores, por su parte, en una evolución cronológica (The darker side 256), lo cual da lugar, así, a una fisura entre el concepto de tiempo unido a la cosmología y a la religión y el concepto de tiempo atado a la administración; un concepto de espacio ligado al cuerpo y a la comunidad, y un concepto de espacio ligado a la proyección geométrica y el cálculo aritmético (The darker side 226). Serge Gruzinski ha señalado al respecto que la percepción lineal y descontextualizada de la historia indígena hizo abstracción de dimensiones propias, encerrándolas en esferas circunscritas por categorías occidentales (La colonización 100).

Al fabricar una continuidad entre el mundo occidental y el americano, las imágenes clásicas de la Crónica de los Reinos de Chile instalan, no obstante, una discontinuidad que tiene consecuencias inmediatas en el proyecto de conquista: la historia indígena (en cuanto parte de esa historia "universal" de conquistas) desembocaría necesariamente en la conquista española del siglo XVI, entendida entonces como hito de una trayectoria lineal; el pasado autóctono es tematizado exclusivamente en relación con esa trayectoria que pretende conducir a un desenlace colonial y cristiano (Gruzinski, La colonización 83). En esa cronología, la conquista inca aparece como "antecedente" de ese desenlace: antecedente rastreado con insistencia por el cronista burgalés, como si constituyera el punto más antiguo (y significativo) en el pasado de las culturas autóctonas descritas.

La inscripción del pasado indígena en esa historia universal de conquistas pone en el centro el aspecto bélico-militar, en detrimento de las conceptualizaciones fundadas en la mitología y cosmología locales. Aun el contenido 
bélico-militar, fundamental en la caracterización que hace Vivar de los araucanos, es privado de elementos significativos para las culturas americanas, como el ritual. Estudiosos de la cultura mapuche coinciden en la atribución de contenido ritual a la acción bélica. Foerster señala que "en la sociedad mapuche la guerra debe haber sido uno de los tantos mecanismos rituales inscritos dentro de esta lógica [de] circulación de la energía sagrada" pues "hombres y dioses luchaban activamente por igual contra el huinca, tanto en el MAPU (tierra) como en el WENUMAPU (cielo)" (139). Bengoa, por su parte, supone que la "guerra ritual" presidió los primeros enfrentamientos de los mapuches con los españoles, de acuerdo con el sentido antiguo de la guerra que posibilitaba, en cuanto demarcación simbólica de límites y fronteras, el establecimiento de alianzas y, en última instancia, la convivencia entre grupos (225). La invasión española supuso, para la cultura mapuche, la ruptura del equilibrio cósmico que, por medio de la guerra ritual, se intentó reestablecer (Bengoa 239). Así, la continuidad establecida por Vivar entre mapuches, numantinos y cartagineses oblitera la dimensión sacrificial del guerrero araucano que enfrentaba la muerte en la expectativa de seguir participando en la lucha desde el mundo de arriba, junto a sus ancestros (Bengoa 239).

\section{CONSIDERACIONES FINALES}

Aquí se vido una cosa admirable que tienen por costumbre, que si una mujer enviuda, tiene el difunto en una barbacoa o cama desnudo y ella le está cada el día llorando. Y como es tan calurosa la tierra, en breve cría gusanos el cuerpo, y ella se los limpia y los toma con sus manos sin asco ninguno, aunque hiede pestíferamente. Y allí está de noche y de día y no se levanta si no es a cosas necesarias que no las puede escusar. Y si por ventura corre alguna grasa del cuerpo, la toma con sus manos y avuelta los gusanos y sin pena se unta ella el cuerpo y el rostro. Y de esta manera se está hasta que el cuerpo se seca y se consume. Toma los huesos y los meten en un cántaro, y allí los tiene guardados. Y éste es su entierro (Crónica 276-7).

El fragmento es una descripción de una práctica mortuoria sabida de oídas por el cronista Jerónimo de Vivar: los españoles que acompañaron a Villagra a la zona de Tucumán se lo habrían relatado. En la descripción, el cronista pareciera renunciar al tamiz de sus categorías y valores inscribiendo lo diferente simplemente en lo admirable. La cita permite reflexionar en 
torno al problema de la construcción del sujeto colonial, en específico, en torno a la relación que indica Rolena Adorno, a partir de una afirmación de Homi Bhabha ${ }^{4}$, entre alteridad e identidad, entre diferencia y semejanza. El colonizado en cuanto realidad fija puede ser al mismo tiempo el otro y lo perfectamente conocible y visible (Bhabha) porque el sujeto "se reconoce a sí mismo reconociendo al otro", la exigencia de definir el carácter del otro es el auto-reconocimiento de los propios límites y el deseo de "diferenciar jerárquicamente el sujeto del otro" (Adorno, "El sujeto" 66). La admiración por la diferencia se advierte en la Crónica en el lejano relato "de oídas" de la viuda de Tucumán que come los gusanos del cuerpo de su difunto marido. En relación con los habitantes del valle del Mapocho y con los "araucanos", se hace indispensable fijar jerarquías a partir de una construcción del sujeto colonial que lo inscribe en un discurso caballeresco militar, ya sea como infiel, ya como guerrero por colonizar.

El examen del sujeto colonial en la Crónica de Vivar permite, además, dar cuenta de la visión colonialista de este discurso. En lo que se refiere al sujeto cronista, al desplazar la cuestión de Vivar de lo biográfico a la polivocalidad, se hace posible subrayar la incidencia de las diversas funciones del cronista en la conquista de Chile en la ideología que fundamenta la Crónica. Se trata de advertir el nivel de compromiso de Jerónimo de Vivar con la empresa de conquista que protagoniza Valdivia: cosmógrafo, secretario, hombre del scriptorium y escriba de algunas cartas de Valdivia, Vivar narra la conquista haciendo al mismo tiempo una defensa del primer gobernador y una propuesta de modelo para el futuro. El modelo se inscribe, como vimos, en la cultura caballeresca militar: el sujeto conquistador actualiza el arquetipo del caballero medieval al tiempo que conjuga estas virtudes con los rasgos del capitán conquistador de Indias. En directa relación con esta figura, el indígena de Chile se moldea en la Crónica a partir de las imágenes del infiel, el bárbaro, el amigo del demonio y el guerrero bestial cuya valerosidad se contrapone a la de los españoles, seguidores de romanos en el Nuevo Mundo de Indias.

4 "Colonial power produces the colonize as a fixed reality which is at once an 'other' and yet entirely knowable and "visible"" En "The other question: difference, discrimination and the discourse of colonialism". 


\section{BIBLIOGRAFÍA}

Adorno, Rolena. "Nuevas perspectivas en los estudios literarios coloniales hispanoamericanos". AA.VV. Lectura crítica de la literatura americana. Inventarios, invenciones y revisiones. Caracas: Biblioteca Ayacucho, 1996. 664-677.

"El sujeto colonial y la construcción cultural de la alteridad". Revista de Crítica Literaria Latinoamericana. XIV/28 (1988): 55-68.

Ainsa, Fernando. De la Edad de Oro a El Dorado. Génesis del discurso utópico americano. 1992. México: Fondo de Cultura Económica, 1998.

Altuna, Elena. El discurso colonialista de los caminantes (siglos XVII-XVIII). Michigan: Centro de Estudios Literarios “Antonio Cornejo Polar” y Latinoamericana Editores, 2002.

"Introducción. Relaciones de viajes y viajeros coloniales por las Américas". Revista de Crítica Literaria Latinoamericana. XXX/ 60 (2004): 9-23.

Antei, Giorgio. La invención del reino de Chile: Gerónimo de Vivar y los primeros cronistas chilenos. Bogotá: Instituto Caro y Cuervo, 1989.

Bhabha, Homi K. "The other question: difference, discrimination and the discourse of colonialism". Literature, Politics, and Theory. Ed. Francis Baker, Meter Hulme, Margaret Iversen, Diane Loxley. London: Methuen, 1986. 148-172.

Barral Gómez, Ángel. “Introducción”. Crónica de los reinos de Chile. De Jerónimo de Vivar. Madrid: Historia 16, 1988. 7-36.

Barros Arana, Diego. Historia General de Chile. Tomo II. Santiago: Editorial Jóver, 1884.

Bengoa, José. Historia de los antiguos mapuches del sur. Santiago: Catalonia, 2003.

Buarque de Holanda, Sérgio. Visão do Paraíso. São Paulo: Brasiliana, 1969.

Bueno, Raúl. "Sujeto heterogéneo y migrante. Constitución de una categoría de estudios culturales". Antonio Cornejo Polar y los estudios latinoamericanos. Ed. Friedhelm SchmidtWelle. Pittsburgh: Instituto Internacional de Literatura Iberoamericana, 2002. 173-194.

Duviols, Pierre. La destrucción de las religiones andinas (Conquista y Colonia). Trad. Algor Maluenda. México: Universidad Nacional Autónoma de México, 1977.

Ferreccio Podestá, Mario. "El epistolario cronístico valdiviano y el scriptorium de conquista". Cartas de Don Pedro de Valdivia que tratan del descubrimiento y conquista de la Nueva Extremadura. Ed. Facsimilar al cuidado de Rojas Mix. Notas y transcripción por Mario Ferreccio. Barcelona: Lumen, 1991. 33-53.

Foerster, Rolf. Introducción a la religiosidad mapuche. Santiago: Editorial Universitaria, 1993.

Góngora Marmolejo, Alonso de. Historia de todas las cosas que han acaecido en el Reino de Chile y de los que lo han gobernado (1536-1575). Santiago: Ediciones de la Universidad de Chile, 1990.

Góngora, Mario. Estudios sobre la historia colonial de Hispanoamérica. Santiago: Editorial Universitaria, 1998.

Gruzinski, Serge. La colonización de lo imaginario. 1988. Trad. Jorge Ferreira Santana. México: Fondo de Cultura Económica, 2004. 
Invernizzi, Lucía "La representación de la tierra de Chile en cinco textos de los siglos XVI y XVII". Revista Chilena de Literatura. 23 (1984): 5-37.

"Los trabajos de la guerra y los trabajos del hambre: dos ejes del discurso narrativo de la conquista de Chile (Valdivia, Vivar, Góngora Marmolejo)". Revista Chilena de Literatura. 36 (1990): 7-15.

"La probanza de servicios y méritos en las Cartas de Pedro de Valdivia o el valor de los trabajos de la guerra y los trabajos del hambre" Cartas de Don Pedro de Valdivia que tratan del descubrimiento y conquista de la Nueva Extremadura. Ed. Facsimilar al cuidado de Rojas Mix. Notas y transcripción por Mario Ferreccio. Barcelona: Lumen, 1991. 249-263.

Kordić, Raïssa. "Nueva edición de la Crónica de Vivar". Boletín de Filología XLII (2007): 389-395.

León Pinelo, Antonio de. Epítome de la biblioteca oriental y occidental, náutica y geográfica. Madrid: Oficina de Francisco Martínez Abad, 1737. Edición digital en: http://www. cervantesvirtual.com/FichaObra.html?Ref $=4279$

López de Gomara, Francisco. Historia general de las Indias. Tomo I. Madrid: Calpe, 1922.

Medina, José Toribio. Ed. Colección de documentos inéditos para la historia de Chile. Primera Serie. Santiago: Imprenta Elzeviriana, 1900.

Mignolo, Walter. The darker side of the Renaissance. 1995. Michigan: The University of Michigan Press, 2003.

Montt, Luis. "Primeros cronistas de Chile". Revista Chilena VI (1876).

Orellana, Mario. La crónica de Gerónimo de Vivar y la conquista de Chile. Santiago: Editorial Universitaria, 1988.

La Crónica de Gerónimo de Bibar y los primeros años de la conquista de Chile. Santiago: Librotecnia Editores, 2006.

Pagden, Anthony. La caida del hombre natural. 1982. Madrid: Alianza, 1988.

Pastor, Beatriz. Discursos narrativos de la conquista: mitificación y emergencia. Hanover: Ediciones del Norte, 1988.

Romero, José Luis. Sobre la biografía y la historia. Buenos Aires: Sudamericana, 1945.

Valdivia, Pedro de. Cartas de Don Pedro de Valdivia que tratan del descubrimiento y conquista de la Nueva Extremadura. Ed. Facsimilar al cuidado de Rojas Mix. Notas y transcripción por Mario Ferreccio. Barcelona: Lumen, 1991.

Vicuña Mackenna, Benjamín. "Juicio crítico de la Historia general de Chile, obra inédita del jesuita Diego de Rosales”. Anales de la Universidad de Chile XLI (1872): 5-29.

Villalobos, Sergio. "Tras los pasos de un cronista". Prólogo. La crónica de Gerónimo de Vivar y la conquista de Chile. De Mario Orellana. Santiago: Editorial Universitaria, 1988. 9-16.

Vivar, Jerónimo de. Crónica de los reinos de Chile. Ed. Ángel Barral Gómez. Madrid: Historia $16,1988$. 